Sitasi artikel ini (APA $6^{\text {th }}$ Edition style):

Siswanto, D. T. B., \& Lestari, S. N. (2018). Afdeeling Berbek Pasca Pemindahan Ibukota: Tinjauan Historis Perkembangan Nganjuk sebagai Pusat Pemerintahan Baru, 1880-1901. MUKADIMAH, 2(1), 1-10.

\title{
Afdeeling Berbek Pasca Pemindahan Ibukota: Tinjauan Historis Perkembangan Nganjuk sebagai Pusat Pemerintahan Baru, 1880-1901
}

\author{
Depy Tri Budi Siswanto dan Siska Nurazizah Lestari \\ Program Studi Pendidikan Sejarah, Fakultas Keguruan dan Ilmu Pendidikan, \\ Universitas Nusantara PGRI Kediri, Kota Kediri \\ depysiswanto@gmail.com dan siskahistoria2005@gmail.com
}

\begin{abstract}
ABSTRAK
Penelitian historis ini menjelaskan perkembangan Nganjuk sebagai ibukota baru Afdeeling Berbek. Berbek merupakan daerah di bawah kekuasaan Keresidenan Kediri. Pada tahun 1830 hingga 1880, ibukota pemerintahan afdeeling ini berada di Berbek, lokasinya berada di lereng Gunung Wilis yang terisolasi. Pada tahun 1878, terjadi pergantian kekuasaan di Berbek, yaitu diangkatnya Sosrokoesomo III sebagai bupati baru. Pemikirannya yang revolusioner, mencetuskan suatu ide pemindahan pusat pemerintahan. Pertimbangan utamanya adalah terisolasinya wilayah Berbek, untuk itu dipilihlah Nganjuk sebagai ibukota baru. Nganjuk dipilih sebagai pusat pemerintahan baru karena jalur kereta api Surabaya-Solo melewati kota ini dan sangat potensial untuk dijadikan sebagai ibu kota. Sejak ibukota dipindahkan ke Nganjuk pada tahun 1880, perkembangan kota berlangsung secara luar biasa. Pembangunan Nganjuk bukan semata tentang estetika ibu kota yang baru, namun juga untuk mempermudah administrasi pemerintahan. Pembangunan kota Nganjuk mempengaruhi kehidupan sosialekonomi masyakrakat hingga sekarang.
\end{abstract}

Kata kunci: Afdeeling Berbek, pemindahan ibukota, Nganjuk, Sosrokoesomo III.

\section{PENDAHULUAN}

Wilayah Berbek dan Nganjuk sudah lama disebut dalam sejarah Nusantara. Pada era kerajaan Islam misalnya, wilayah Berbek beberapa kali disebut dalam Manuskrip Instruksi Amangkurat II, tanggal 2 Desember 1677 yang menyebutkan jumlah cacah di Mancanegara ${ }^{1}$ Wetan yang diantaranya terdapat Berbek dan Nganjuk (Sukardi, 2014, p. 6). Berbek memiliki 700 cacah $^{2}$, dan Nganjuk 450 cacah (Pranoto, 2010, p. 86; Sukardi, 2014, p. 179). Wilayah-wilayah Mataram Islam hingga Berbek tidak sulit untuk dipahami sejarahnya mengingat konsolidasi awal yang dilakukan Panembahan Senopati juga sudah sampai ke wilayah Kertosono, Kediri, Mojokerto hingga Surabaya (Olthof, 1941, p. 99). 
Awal Berbek dan Nganjuk masuk wilayah kolonial setidaknya dapat diketahui pada tahun 1811 (Carey, 1984). Kemungkinan sebelum tahun tersebut ada tendensi bahwa kedua wilayah ini sudah dikuasai atau menjadi daerah pengawasan antara kolonial dan suzereinitas pecahan Mataram Islam. Hal ini karena terjadi beberapa perjanjian seperti Perjanjian Giyanti yang menyebutkan perpecahan wilayah Nganjuk. Dalam perjanjian tersebut disebut pula wilayah di Nganjuk seperti Pace dan Kertasana dalam kekuasan Kasunanan dan Kasultanan. Namun tidak disebut wilayah Nganjuk dan Berbek. Hal ini dimungkinkan bahwa Berbek dan Nganjuk kala perjanjian itu sudah masuk wilayah pengawawan kolonial (Achmad, 2016, pp. 182-183).

Pada tahun 1831, Berbek merupakan afdeeling di bawah administrasi Keresidenan Kediri, dengan Sosro Koesoemo I sebagai bupati. Peninggalan bersejarah yang masih ada sampai sekarang adalah Masjid Yoni Al-Mubarok dan alun-alun Berbek. Ibukota ini dipertahankan posisinya hingga tahun 1880. Ibukota pemerintahan memiliki peran yang paling esensial jika dilihat pada perkembangan suatu kekuasaan. Pemerintahan daerah pada era kolonial akan sangat merugi jika ibukota pemerintahannya terisolasi oleh alam dan sulit berkembang. Hal ini yang terjadi pada Berbek yang ibukota lamanya berada di daerah lereng Gunung Wilis yang terisolasi oleh alam. Tentunya banyak pertimbangan lain selain masalah isolasi alam tersebut.

Pemindahan ibukota ini tidak terlepas dari pemikiran Sosrokoesomo III. Bupati ini menggantikan bupati lama dengan nama Somo Wilojo, ayahnya yang mangkat. Pengangkatannya disahkan dalam Besluit Gubernur Jenderal, 10 April 1878. Dalam surat kepustusan tersebut juga dapat diketahui bahwa Raden Mas Sosrokoesoemo III sebelum menjadi bupati merupakan seorang Wedono Tulungagung (Afdeeling Ngrowo). Bupati ini dikenal sangat cakapdan lebih ungul dari segala sisi ketimbang pada calon-calon lain yang dipertimbangkan oleh Keresidenan Kediri. Gagasanya dalam memindahkan ibukota Afdeeling Berbek dari Berbek ke Nganjuk. Suatu revolusi yang sangat berdampak bagi berkembangnya afdeeling tersebut, di masa lalu, sekarang, dan masa yang akan datang.

\section{HASIL DAN PEMBAHASAN}

\section{Sejarah Nganjuk sebelum 1880}

Pemindahan ibukota dari Berbek ke Nganjuk, bukan berarti Nganjuk sebagai tempat kosong dan tidak berpenghuni. Nganjuk merupakan afdeeling yang pernah berdampingan dengan Berbek sebagai daerah tingkat Kabupaten di bawah pengawasan Keresidenan Kediri. Jadi, pemindahan ini menjadi membingungkan ketika tidak ada data yang menjelaskan mengenai serah terima kekuasaan antara Afdeeling Berbek dan Nganjuk ataupun proses fusi di dalamnya.

Dalam Babad Panembangan dijelaskan bahwa Bupati Nganjuk yang mungkin bupati pertama (berdasarkan temuan sejauh ini) adalah R.M. Arya 
Jayadiningrat. Sebelum menjadi Bupati Nganjuk, dia adalah Wedana Kaparak Kiwa Keraton Surakarta. R.M. Arya Jayadiningrat merupakan keturunan dari B.R.A. Sentul, Putri Pakubuwono III, yang menikah dengan R.M.T. Sumadiningrat, putra Hadiwijaya I Kalibabu, Pakubuwono III (Damari \& Efendy, 2014, p. 29). Sementara itu, secara lebih jelas Afdeeling Nganjuk dengan stakeholder-nya dan secara de jure masuk wilayah kekuasaan kolonial, dapat dilihat dalam Lampiran Resolutie, 3 Juli 1830. Dalam lampiran Perjanjian Sepreh tersebut disebut nama Radeen Tommongong (Raden Tumenggung) Broto di Korro, Regent van Ngandjook (Nganjuk). ${ }^{3}$ Hal ini menunjukan bahwa Nganjuk adalah daerah yang berdampingan dengan Afdeeling Berbek. Adapun pejabat Inlandsche Afdeeling adalah sebagai berikut:

\begin{tabular}{lll}
\hline \multicolumn{1}{c}{ Gelar } & \multicolumn{1}{c}{ Nama } & \multicolumn{1}{c}{ Jabatan } \\
\hline Raden Tumenggung & Brotto di Korro & Bupati \\
\hline Mas Ngabei & Mang-oon Karjo & Pattih \\
\cline { 2 - 3 } & Dermo Wi Djojo & Mantri \\
\cline { 2 - 3 } & Rogo Joedo & Mantri \\
\cline { 2 - 3 } & Mang-oon Karso & Mantri \\
\cline { 2 - 3 } & Mang-oon Prawiro & Jaksa \\
\cline { 2 - 3 } & Mohamad Tahar & Penghulu \\
\hline Raden Ngabei & Karto di Korro & Mantri Wedono \\
\hline Raden Ronggo & Poespo Ronno & Mantri Wedono \\
\hline
\end{tabular}

Tabel 1. Personil Pemerintahan Afdeeling Nganjuk

Sumber: Besluit, No. 1, 31 Agustus 1830, Bijlage, Semarang, 16 Juni 1831. (w.g.) van Lawick van Pabst (Arsip Nasional Republik Indonesia).

Akhir pemerintahan ini tidak diketahui secara pasti. Dalam salah satu foto bersejarah dapat diperkirakan bahwa Afdeeling Nganjuk masih bertahan sampai tahun 1860. Menurut penafsiran para sejarawan lokal, lokasi pendopo yang tampak pada foto tersebut berada tepat di belakang pendopo Nganjuk yang sekarang. Foto tersebut diambil pada tahun 1860 atau sekitar 20 tahun sebelum ibukota dipindahkan dari Berbek ke Nganjuk. Berarti pada tahun itu ada fakta keras bahwa Afdeeling Nganjuk masih berdiri.

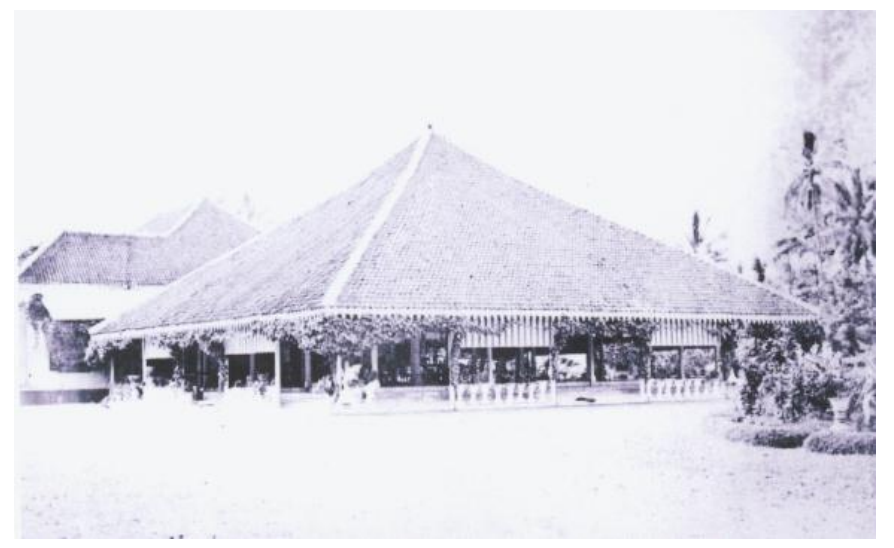

Gambar 1. Pendopo Nganjuk 1860

Sumber: Badan Arsip Daerah Kabupaten Nganjuk 


\section{Boyongan dari Barbek ke Nganjuk, 1880}

Sejauh ini faktor utama yang dapat diketahui sebagai alasan pemindahan pusat pemerintahan dari Berbek ke Nganjuk adalah terisolasinya Berbek sebagai ibukota. Wilayahnya berada di lereng Gunung Wilis, permukaan tanah yang berbatu, dan sulit berkembang. Hal ini mempengaruhi pola hidup masyarakat Berbek. Ini merupakan salah satu pertimbangan bahwa isolasi bukanlah satusatunya sebab ibukota akhirnya dipindahkan.

Menurut keterangan dalam Encyclopaedie van Nederlandsch-Indië, disebutkan bahwa alasan pemindahan pusat pemerintahan dari Berbek ke Nganjuk adalah karena dibangunnya jalur kereta api Surabaya-Solo (Paulus \& Stibbe, 1919, pp. 274-275). Hal ini membuat wilayah Nganjuk semakin ramai, karena jalur kereta api ini juga memuncukan jalur perdagangan baru. Pemindahan pusat pemerintahan direalisasikan pada tahun 1883. Sementara itu, menurut pendapat lain seperti Harimintadji menyebut pemindahan pusat pemerintahan dilakukan pada 21 Agustus 1880 (Harimintadji, Santoso, Suranto, \& Suwarno, 2003, p. 82). Momentum inilah yang diyakini oleh masyarakat sekarang sebagai hari Boyongan (memindahkan) ibukota dari Berbek ke Nganjuk.

Pemindahan tersebut dilakukan oleh Sosrokoesoemo III berdasarkan hasil pemikiran yang tentunya dipertimbangkan secara matang. Kebijakan Sosrokoesomo III sebagai Bupati Afdeeling Berbek dalam memindahkan ibukota tentu bukan hanya kebijakan pribadinya. Dalam hal ini pemerintah Keresidenan Kediri dan pemerintah kolonial tentu mengetahui dan ikut mempertimbangkan kebijakan tersebut. Terkadang dengan subjektifitas kedaerahan yang tinggi sejarawan menafikan hal yang dirasa penting seperti hal diatas, dan memunculkan tokoh-tokoh yang ia sukai dengan dibubuhi superioritas tinggi mejadi tokoh utama dalam suatu peristiwa.

\section{Pembangunan Nganjuk sebagai Ibukota Baru}

Informasi mengenai Nganjuk sebagai ibukota baru dari Afdeeling Berbek dapat dilihat dalam Staatsblad van Nederlandsch-Indië tanggal 30 Mei 1885 No. 4/c. Di dalamnya dijelaskan bahwa Nganjuk menjadi ibukota dari Afdeeling Berbek, di mana kampung-kampung dan desa-desa di sekitarnya juga disebut, yaitu Kampung Cina, Desa Mangoendikaran, Desa Pajaman, dan Desa Kauman. Desa-desa tersebut merupakan desa awal yang sudah ada sebelum pemindahan pusat pemerintahan ini terjadi.

Menjadi perhatian utama disini, bahwa tidak ada pergantian nama dari Afdeeling Berbek menjadi Afdeeling atau Regentschap Nganjuk (Baru). Pemindahan ini bukan menjadi sesi pergantian nama institusi pemerintahan kolonial terebut. Setidaknya hingga pemerintahan Sosrokoesomo III berakhir namanya tetap Afdeeling Berbek, dan Nganjuk adalah ibukotanya. Menyebut regentschap untuk daerah Berbek di Nganjuk pasca pemindahan merupakan sebuah anakronisme. 
Pemindahan ini membuat perubahan Nganjuk secara drastis. Dilakukannya pemindahan ini menjadikan Nganjuk menjadi lebih besar dari sebelumnya. Banyak bangunan-bangunan baru yang didirikan. Sebagaian dari bangun ini seperti masjid, alun-alun, pendopo dan pasar merupakan bentuk mikro dari bentuk makro ibukota Kerajaan Mataram. Pola ini diikuti oleh seluruh daerah di era kolonial khusunya di wilayah Jawa Timur dan Jawa Tengah. Adapun bangunan lain yang didirikan berkaitan dengan administrasi pemerintahan, seperti kantor pos, stasiun, rumah sakit. Aspek-aspek ekonomi juga diperhatikan dibuktikan dengan dibangunnya vila dan perumahan pegawai serta pabrik gula yang dapat memobilisasi rakyat di area Afdeeling Berbek untuk memiliki pekerjaan. Berikut berbagai bentuk pembangunan yang terjadi di Nganjuk.

\section{Jalur Kereta Api}

Kereta api di Nganjuk tidak terlepas dari pembangunan rel kereta api Surabaya-Solo. Keadaan politik kolonial setelah Perang Jawa, dirasa perlu untuk mempermudah distribusi dengan modernisasi sarana transportasi terutama sejak diberlakukannya Sistem Tanam Paksa untuk mengangkut komoditas dalam jumlah besar.

Demikian pula yang terjadi pada perkebunan tebu di Berbek dengan kondisi geografis yang kurang strategis untuk mengangkut tebu dari perkebunan ke pabrik, sehingga perbaikan dan pengembangan transportasi mulai dibangun di Nganjuk, tujuannya untuk menciptakan sarana pengangkutan yang memadai untuk memudahkan proses pengangkutan serta meningkatkan hasil perkebunan (Prasetyo, 2015, p. 91).

Jalur rel kereta api melewati Afdeeling Kertosono, Distrik Baron, hingga wilayah Nganjuk sendiri. Dalam Staatsblad van Nederlandsch-Indië tanggal 29 September 1882 No. 234 dijelaskan bahwa setelah pemindahan pusat pemerintahan, pembangunan jalur rel kereta api di Nganjuk belum selesai. Peresmian jalur kereta api di wilayah Nganjuk dan sekitarnya tidak terjadi bersamaan. Jalur Sembung-Kertosono diresmikan pada tanggal 25 Juni 1881; jalur Kertosono-Kediri pada tanggal 13 Oktober 1881; jalur Kertosono-Nganjuk pada tanggal 1 Oktober 1881; dan jalur Nganjuk-Madiun pada tanggal 1 Juni 1882 (Harimintadji, 2002, p. 44). Hal demikian menandai bahwa pembangunan kereta api merupakan proyek jangka panjang, yang melewati wilayah Nganjuk. Akan lebih mudah pembangunan proyek ini jika ibukota lebih didekatkan dan supervisi yang dilakukan terhadap proyek tersebut jauh lebih mudah.

2. Masjid Agung Baitussalam

Masjid berperan penting sebagai tempat ibadah umat Islam. Ketika Afdeeling Berbek belum dipindahkan ke Nganjuk, terdapat masjid besar yang sangat kental akulturasi Hindu, Jawa, China, dan Timur Tengah. Masjid itu menjadi monumen kejayaan Afdeeling Berbek dari era Sosrokoesomo I hingga sekarang. Masjid tersebut bernama Masjid (Yoni) Al-Mubarok Berbek yang terletak di sebelah barat alun-alun Berbek. Masjid itu diperkirakan dibangun sekitar tahun 
1831. Ada beberapa masjid lain yang dapat diakui sebagai warisan sejarah. Misalnya di Nganjuk, di sana terdapat Masjid Agung Baitussalam.

Masjid Agung Baitussalam Nganjuk merupakan bukti awal pemindahan pusat pemerintahan dari Berbek ke Nganjuk. Terdapat beberapa candrasangkala dalam masjid ini yang memiliki relevansi dalam pemindahan pemerintahan pada era Sosrokoesomo III. Candrasangkala tersebut adalah: (1) Sebelah utara luar, "Hingkang yasa mimbar puniko Kyai Haji Penghulu Bagus Alhaji Mohammad Yacub"; (2) Sebelah utara bagian dalam, "Adegipun masjid kita Nganjuk" tahun Jawi 1814 tahun Jawi 1813; (3) Sebelah timur luar, "Dal Hijrotun Nabiy dadosipun Mimbar"; (4) Bagian timur dalam, "Hijrotun Ghoziyatun"; (5) Sebelah selatan luar "Ngalih ipun negari saking Berbek, Bupati Kanjeng Adipati Sosrokoesoemo Tahun Walandi 1880" (Harimintadji et al., 2003, p. 123).

Candrasangkala tersebut juga mengungkap bahwa pemindahan pusat pemerintahan benar terjadi pada tahun 1880. Sesuai dengan candrasangkala tersebut pula Harimintadji, berpendapat bahwa masjid tersebut dibangun tahun 1884 (Harimintadji et al., 2003). Tahun ketika ibukota sudah dipindahkan. Untuk itu masjid ini sangat penting dalam penelusuran sejarah pemindahan pusat pemerintahan Afdeeling Berbek ke Nganjuk.

Mengenai pembangunan masjid Agung, masjid ini dibangun berdasarkan kosmologi dan magic religius. Berdasarkan konsep tersebut, bangunan masjid selalu melengkapi bangunan kraton, terletak di dekat alunalun, yang pada hakikatnya adalah sesuai dengan azas "mocopat" dari zaman prasejarah. Berdasarkan azas tersebut di sekeliling alun-alun biasanya terdapat bangunan istana, masjid pasar dan rumah penjara. Kota Nganjuk jika dikaitkan dengan konsep tersebut justru lebih lengkap. Sebelah timur alun-alun terdapat Pendopo kabupaten, sebelah selatan terdapat pusat pertokoan (pasar), sebelah barat terdapat masjid dan rumah penjara, dan sebelah utara terdapat Kantor Polisi (keamanan) dan sekolahan (Harimintadji et al., 2003, p. 122).

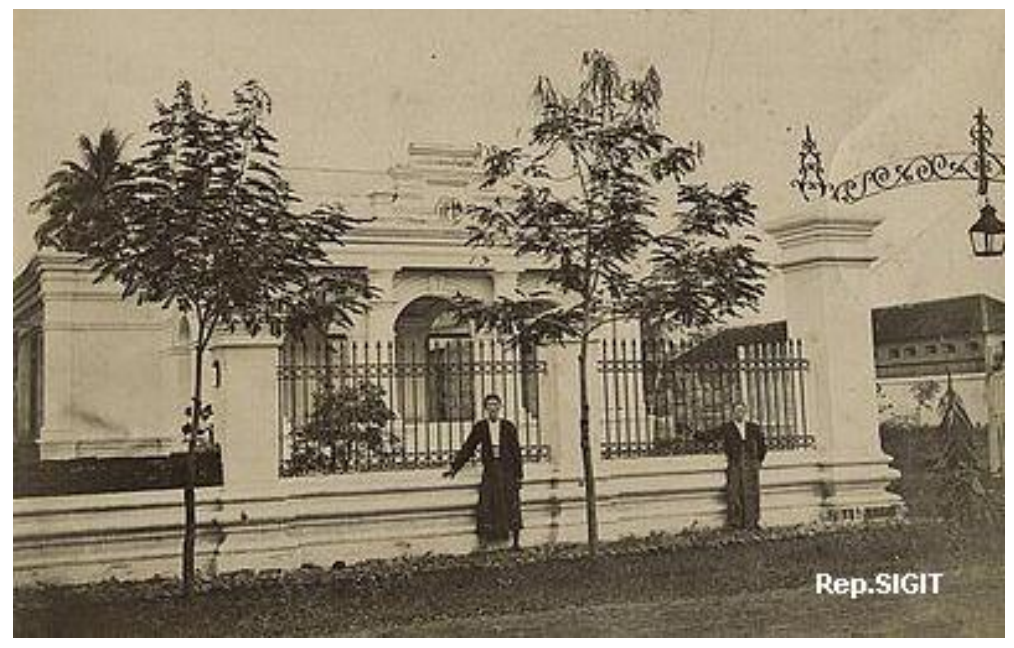

Gambar 2. Masjid Agung Baitusslam 1885

Sumber: Badan Arsip Daerah Kabupaten Nganjuk 
Bangunan Masjid Agung Baitussalam ini berdiri di atas tanah seluas, $2.424 \mathrm{~m}^{2}$ dan luas bangunannya $1.124 \mathrm{~m}^{2}$. Di sebelah timur terdapat pintu masuk, pintu utama (paling lebar) terdapat di tengah-tengah, sedangkan di sebelah (selatan) pintunya lebih kecil. Memasuki halaman depan kita segera memasuki serambi masjid yang disangga oleh tiang beron yang kokoh berjumlah 6 buah. Di sebelah serambi terdapat bedug besar. Dari serambi memasuki ruang utama terdapat 5 pintu dengan motif relung yang berukuran sama. Masjid Agung ini disangga oleh 8 tiang utama, 4 tiang berbentuk persegi panjang terbuat dari beton dan 4 tang lagi berbentuk bulat panjang yang berukuran lebih tinggi dari 4 tiang lainnya, karena tiang tersebut langsung menyangga atap utama yang tertinggi. Pada dinding kanan dan kiri terdapat 2 pintu dan 6 jendela yang semuanya dengan motif relung. Di sebelah barat ruang utama terdapat mihrab yang relatif luas, yang di kanan dan kirinya terdapat kamar yang dipergunakan sebagai tempat penyimpanan benda/barang yang ada kaitanya dengan kegiatan masjid.

\section{Kantor Pos Nganjuk}

Di Nganjuk tersedia akses jalan kereta api, sehingga memudahkan bagi daerah ini untuk menerima informasi dan melakukan komunikasi dengan daerah lain. Dalam proses surat-menyurat di wilayah Afdeeling Berbek dibangun 3 kantor pos pembantu yang tersebar di beberapa distrik pada tahun 1881 (Urokhim, 2010, p. 87). Pembangunan kantor pos pembantu pertama yang berada di Nganjuk dilakukan pada tanggal 31 Januari 1881 (Staatsblaad van Nederlandsch Indië tanggal 31 Januari 1881 No. 43). Setelah pembangunan yang pertama, pada tanggal 25 Juni 1882 didirikan pos kuda yang menghubungkan komunikasi dari Nganjuk ke Kediri (Staatsblaad van Nederlandsch Indië, tanggal 25 Juni 1882 No. 174). Keunikan cara pengiriman surat kala itu adalah kuda digunakan sebagai alat transportasi surat antara Nganjuk ke Kediri dan sekitarnya. Pendirian kantor pos terkahir berada di Kertosono dan sudah diresmikan penggunaanya pada tahun 1883.

\section{Pabrik Gula Nganjuk}

Beberapa wilayah Nganjuk jenis tanahnya sangat potensial dalam pengolahan tanaman perkebunan. Tebu merupakan tanaman yang memiliki sejarah panjang di Nganjuk sejak masa tanam wajib (tanam paksa). Ada beberapa bangunan dari pabrik gula era kolonial yang masih bertahan hingga sekarang di Nganjuk.

Luas areal tanam wajib di Keresidenan Kediri pada tahun 1833 seluas 642 bau mengalami peningkatan pada tahun 1860 menjadi 1900 bau, sampai pada akhir tahun 1901 jumlah lahan perkebunan meningkat tajam hingga mencapai 20.000 bau. Lahan areal tanam wajib di Berbek sampai pada tahun 1890 tidak mengalami perubahan, demikian juga dengan pembagian wilayah administrasinya. Permasalahan lain yang muncul dari penanaman tebu secara paksa ini adalah pengangkutan hasil dari perkebunan yang dirasa sangat sulit, karena kondisi geografis wilayah Berbek yang berupa pegunungan dan 
berjalan terjal membuat proses pengangkutan ke pabrik-pabrik gula dan pelabuhan berjalan lambat (Prasetyo, 2015, p. 30). Ketika ibukota dipindahkan, urusan-urusan perkebunan, penanaman dan distribusi menjadi lebih mudah. Sejak itu, pabrik gula mulai banyak muncul.

Pabrik-pabrik gula di wilayah Nganjuk dikuasai oleh pengusaha swasta, di antaranya adalah Pabrik gula di District Waruja dimiliki oleh Liem Tik Koej dan J.W. Lucus dengan luas mencapai 336 bau; dan Pabrik gula di Distrik Gemenggeng dimiliki N.J. Land Bouw de Nam dengan luas mencapai 534 bau (Urokhim, 2010, p. 82). Selain itu, ada beberapa pabrik gula lain seperti di Loceret (Godean), dan Patianrowo. Pembangunan pabrik gula ini mampu meningkatkan ekonomi daerah Nganjuk. Masyarakat bisa bekerja sebagai buruh tani, buruh di pabrik, hingga juru tulis di industri gula.

\section{Handels Vereeniging Amsterdam (HVA) di Nganjuk}

Dibangunya pabrik gula berarti ada lembaga kesehatan yang didirikan oleh pabrik tersebut sebagai standarisasi pekerjaan. Lembaga tersebut dapat berupa klinik, dokter jaga, ataupun rumah sakit. Di Hindia Belanda dikenal Handels Vereeniging Amsterdam (HVA) dan lembaga ini berdiri di Nganjuk dan Kertosono. Mulanya, pemerintahan kolonial membentuk HVA di daerah kekuasaan kolonial yang terdapat perusahaan-perusahaan Belanda pada tahun 1873. Organisasi tersebut didirikan untuk mengatur kegiatan perdagangan, pengolahan tanah dan kebutuhan kesehatan maupun kebutuhan seluruh karyawan maupun program perusahaan, yang salah satunya adalah kesehatan bagi karyawan perusahaan yang dikelola Belanda.

HVA awalnya dikhususkan untuk karyawan perusahaan, dideklarasikan oleh para tokoh agama yang peduli dengan dengan kesehatan di Jawa Tengah khususnya di perusahaan penggilingan tebu. Tokoh agama bekerja sama dengan pengusaha pabrik untuk mendirikan klinik kesehatan yang diperlukan oleh semua karyawan. Dengan berdirinya klinik kesehatan di sekitar perusahaan, banyak memanfaatkannya. Selain itu juga sudah ada klinik kesehatan yang lain namun belum bisa menyentuh rakyat kecil. Sedangkan di daerah Nganjuk sendiri ketika itu terdapat klinik HVA, juga ada klinik kesehatan umum yang didirikan oleh pemerintah setempat (Purwadi, Damari, Handoko, Syifa, \& Pratignyo, 2014, pp. 11-13).

HVA di Nganjuk didirikan oleh Bupati Sosrokoesoemo III antara tahun 1890-1895, yang merasa kurang lengkap ketika pemerintahannya belum ada fasilitas kesehatan umum masyarakat Nganjuk, yang pada masa itu masih mengandalkan kesehatan atau dokter dari Kediri. Klinik kesehatan pertama kali berdiri di wilayah timur, yang meliputi pabrik gula Lestari, Juwono, Purwoasri, dan Kujon Manis. Klinik HVA Kertosono sendiri berdiri diperkirakan pada tahun 1880 hampir bersamaan dengan klinik di daerah Blitar 1890 (Purwadi et al., 2014, p. 67).

Pembangunan Nganjuk sebagai ibukota baru tidak berhenti sampai di situ saja. Banyak pembangunan lain yang diteruskan. Ketika Sosrokoesomo III 
dipensiunkan sebagai bupati Berbek, wilayah Nganjuk mulai dibangun. Pembangunan lanjutan dilakukan oleh Sosrohadikoesoemo sebagai bupati pengganti Sosrokoesomo III.

\section{PENUTUP}

Pemindahan pusat pemerintahan dari Berbek ke Nganjuk pada tahun 1880 berdampak pada berkembangnya Nganjuk sebagai ibukota baru. Perkembangan tersebut terwujud dalam bentuk bangunan-bangunan administratif, ekonomi, bahkan kesehatan. Pembangunan ini adalah wujud dari perkembangan wilayah Nganjuk akibat pemindahan pusat pemerintahan Berbek. Pembangunan yang paling penting adalah jalur kereta api dari Surabaya hingga Solo yang melewati Nganjuk. Antara tahun 1881-1883, jalurjalur yang melewati Nganjuk tersebut diresmikan. Pembangunan selanjutnya adalah Masjid Agung Baitussalam yang dibangun pasca pemindahan pusat pemerintahan. Di Afdeling Berbek terdapat tiga kantor pos yang dibangun antara tahun 1881-1883. Adapula kantor pos kuda yang menggunakan kuda sebagai alat transportasi. Sementara itu, pembangunan di sektor ekonomi ditandai dengan pembangunan pabrik gula di wilayah Nganjuk, Loceret, dan Kertosono. Pembanguan pabrik gula ini juga diikuti dengan pelayanan kesehatan yang disebut yang berada di Nganjuk dan Kertosono.

\section{REFERENSI}

Achmad, S. W. (2016). Babad Giyanti: Palihan Nagari dan Perjanjian Salatiga. Yogyakarta: Araska.

Carey, P. (1984). Changing Javanese perceptions of the Chinese Communities in Central Java 1755-1825 (Orang Jawa \& Masyarakat Cina 1755-1825). (T. P. Aset, Trans.). Jakarta: Pustaka Aset.

Damari, S. H., \& Efendy, A. T. (2014). Kabupaten Pace dalam Lintas Sejarah. Nganjuk: Kantor Perpustakaan dan Arsip Kabupaten Nganjuk.

Harimintadji. (2002). Menguak Tabir Boyongan Ibukota Kabupaten dari Berbek ke Nganjuk. Nganjuk: Tanpa Penerbit.

Harimintadji, H. M., Santoso, Suranto, \& Suwarno. (2003). Menguak Tabir Boyongan Ibukota Kabupaten dari Berbek ke Nganjuk. (H. Nurcahyo, Ed.). Nganjuk: Yayasan Salepuk.

Olthof, W. L. (1941). Poenika Serat Babad Tanah Djawi Wiwit Saking Nabi Adam Doemoegi Ing Taoen 1647. 's-Gravenhage: Martinus Nijhoff.

Paulus, J., \& Stibbe, D. G. (Eds.). (1919). Benthos Berbek. In Encyclopaedie van Nederlandsch-Indië (Zesde Deel). 's-Gravenhage: Martinus Nijhoff.

Pranoto, S. W. (2010). Jawa. Bandit-Bandit Pedesaan: Studi Historis, 1850-1942. Yogyakarta: Graha Ilmu.

Prasetyo, M. D. (2015). Sejarah Pemindahan Ibukota Kabupaten Nganjuk Jawa Timur dari Berbek ke Nganjuk 1880: Tinjauan Historis Pemindahan Pusat Pemerintahan dan Dampaknya Hingga Tahun 1901. UIN Sunan Ampel Surabaya.

Purwadi, A. T. E., Damari, Handoko, R., Syifa, M., \& Pratignyo, L. (2014). Rumah Sakit Umum Daerah Kertosono Kabupaten Nganjuk: Dinamika, Pengabdian dan Kontribusi Sosial dalam Pemberdayaan Kesehatan Masyarakat. 
Yogyakarta: Bangun Bangsa.

Sukardi, T. (2014). Tanam Paksa di Banyumas: Kajian Mengenai Sistem, Pelaksanaan, dan Dampak Sosial Ekonomi. Yogyakarta: Pustaka Pelajar.

Urokhim, A. (2010). Afdeeling Berbek di Bawah Sosrokoesomo III, 1878-1901.

Universitas Airlangga.

${ }^{1}$ Mancanegara adalah sebutan untuk wilayah kerajaan (Mataram Islam) yang berada di luar negaragung tetapi tidak termasuk daerah pantai utara.

2 Cacah adalah kelompok tenaga kerja yang menjadi tulang punggung agar sebidang tanah yang dikerjakan menghasilkan pajak dan upeti.

${ }^{3}$ Resolutie. Bijlage XXV. Perjanjian Sepreh, 3 Juli 1830. (w.g.) van Lawick van Pabst (Arsip Nasional Republik Indonesia). 